\title{
Scoring Sustainability Reports using GRI indicators: A Study based on ISE and FTSE4Good Price Indexes
}

\author{
Hong Yuh Ching (Corresponding author) \\ Business Department, Centro Universitário da FEI (Brazil) \\ Av. Humberto de Alencar Castelo Branco, 3972, São Bernardo do Campo, 09850-901, Brazil \\ Tel: 55-11-4353 2900 E-mail: hongching@fei.edu.br
}

\begin{abstract}
Fábio Gerab
Mathematics Department, Centro Universitário da FEI (Brazil)

Tel: 55-11-4353 2900 E-mail: prifgerab@fei.edu.br
\end{abstract}

Thiago Henrique Toste

Research Student, Centro Universitário da FEI (Brazil)

Tel: 55-11-4353 2900 E-mail: thiago.toste@hotmail.com

Received: March 21, 2014

doi:10.5296/jmr.v6i3.5333
Accepted: May 4, 2014

Published: July 1, 2014

URL: http://dx.doi.org/10.5296/jmr.v6i3.5333

\begin{abstract}
The objective of this research is to verify the level of adherence to the GRI indicators that Brazilian companies listed in ISE and those listed in FTSE4Good are using in their 2011 sustainability reports and what are the differences between these two groups. The research design combines both quantitative and qualitative methods. The target population consists of 70 companies, 35 from ISE and 35 from FTSE4Good. Content analysis was used to analyze the indicators disclosed in the reports and the information presented was classified in three categories of scoring according to its level of disclosure. On average, ISE companies scored 0,5867 and FTSE4Good scored 0,4451. The best company scored 0,924 and the worst of 70 companies scored 0,105. Overall, our statistical results show that ISE companies are more adherent to the GRI indicators than FTSE4Good companies, mainly in the economic and social dimensions. Yet, the companies spay similar attention in all 3 dimensions, regardless of economic sector and index. We can say that good sustainability reports showing deeper
\end{abstract}




\section{Macrothink}

Journal of Management Research ISSN 1941-899X 2014, Vol. 6, No. 3

sustainability concerns and business practices related are acting accordingly to the Stakeholder and Legitimacy theories, regardless of their level of adherence to GRI

Keywords: Sustainability reports, ISE, FTSE4Good, GRI guidelines, Sustainability dimensions 


\section{Introduction}

Sustainability issues are being broadly integrated in different organizational functions and being seen as an important performance assessment. Additionally to financial information, sustainability has been introduced as a reporting subject for companies worldwide in the last few years, addressing the goal of creating a sustainable economy, environment and society. Companies that wish to build a sustainable image are keener on adopting the common practice of elaborating sustainability reports. According to Aktas, Kayalidere and Kargin (2013), reporting sustainability is a key process to inform stakeholders whether the firm is achieving sustainable growth and value for their interest. Stubbs, Higgins and Milne findings (2012) suggest that the route to encouraging greater and better quality uptake of sustainability reporting rests on stakeholders exerting pressure for better and more detailed disclosure from business firms. Although companies rate their performance on communication highly, efforts regarding formal reporting are less advanced. Just $22 \%$ of Economist Intelligence Unit EIU (2008) survey respondents issue formal reports on their environmental and social impact and performance, along with their financial performance (the so-called Triple Bottom Line). Others are preparing to do so: 40\% expect to publish such documents in the next five years. The other 38\% have no plans to, although this does not mean that they are not monitoring these issues.

Corporate sustainability increases market value on the long run, which means that the efforts of taking sustainability into the company strategy seem valuable (Lo and Sheu, 2007). The use of a standard framework for reporting is essentially important for investors, as they get to analyze the reports and compare companies. A standard framework eliminates the risk of uncertainty in measuring different sorts of information (CERES, 2010). Following the same thinking, Isarksson and Staimle (2009) state that reporting guidelines become necessary, since transparency is essential to satisfy and reassure customers and stakeholders expectations with those reports.

The effort to develop guidelines to report and measure sustainability was assessed by some organizations such as Federation des Experts Comptables Europeens FEE (1998), focused on environmental accounting guidance procedures, Public Environmental Reporting Initiative Guidelines PERI (1993), issuing reporting guidelines to help organizations in improving environmental reporting and UNEP-SustainAbility (2000), a scoring system based on 50 topics. The International Integrated Reporting Council IIRC (2013) released its framework recently, offering a set of guidelines to more deeply integrate sustainability into corporate objectives and to holistically account for the value businesses create. Integrated reporting is on its way to becoming the new norm for reporting.

Over time, the reporting guideline that emerged as the dominant framework is the Global Reporting Initiative (GRI). The GRI guidelines are being used by most companies around the world to develop their sustainability reports (Davys and Searcy, 2010). The GRI is the most relevant institution in the sustainability reporting context. GRI hosted in September 2013 in their website 5605 organizations' profile and 14950 sustainability reports of which 14059 are based on GRI framework (data extracted from their website). 
Companies that integrate sustainability in their core business practices and view the subject as an essential long-term performance factor are on radar of investors (KPMG, 2011). Investors' belief that strategies taking sustainability criteria into account have the capacity to create long-term value led to the appearance of sustainability-related indexes linked to financial markets (López et al, 2007). The Dow Jones Sustainability Index (DJSI) was the pioneer in gathering sustainable companies into a unified index, but other stock exchanges, such as Financial Times (in UK) and BM\&FBovespa (in Brazil), have already separate price indexes. Many of these companies make use of sustainability reports as a tool to measure their own performance on the subject (Caron \& Turcotte, 2009).

The objective of this research is to verify the level of adherence to the GRI indicators that Brazilian companies listed in ISE and those listed in FTSE4Good Global Index are using in their 2011 sustainability reports and what are the differences between these two groups. ISE Indice de Sustentabilidade Empresarial is the sustainability related price index at BM\&FBovespa (Brazilian stock exchange) while FTSE4Good Global Index is part of London Stock Exchange FTSE4Good Index series. Both indexes are a good tool for asset owners, investment banks when assessing responsible investment companies.

We test hypotheses relating to whether significant differences exist in the level of adherence to the GRI indicators of companies included in ISE and those in FTSE4Good (hereby identified to as the benchmark sample). They are:

H1 - Reports of companies listed in the FTSE4Good Global Index are more adherent to GRI indicators than those of companies listed in ISE for the economic dimension.

H2 - Reports of companies listed in the FTSE4Good Global Index are more adherent to GRI indicators than those of companies listed in ISE for the environmental aspect.

H3 - Reports of companies listed in the FTSE4Good Global Index are more adherent to GRI indicators than those of companies listed in ISE for the social dimension.

H4 - The level of adherence to the GRI indicators is equivalent for every sustainability dimension within companies of the same index.

The assumption behind the first three hypotheses lies on the fact that FTSE4Good is a more experienced index than ISE (the first was created in 2001, while the latter in 2005) and is associated to a stock exchange with more expressive values when compared to BM\&FBovespa, both in terms of market capitalization (US\$ 15,89 trillion versus US\$ 0,50 trillion approximately as of December, 31, 2013) as number of companies listed (729 versus 38).

The remainder of the paper is organized into four other main sections. The next section is the literature review on studies regarding sustainability and sustainability reports. Methodology and data collection are presented, providing the context necessary for the following section, which presents the discussion of the results and compares them with the ones found in the literature. Finally, the paper finishes with a brief conclusion that summarizes the objectives and findings of this study. 
Our contribution to the sustainability literature is twofold: a) we measure how well corporate sustainability reports from listed companies in two sustainability-related price indexes do regarding the reporting of GRI indicators; b) we demonstrate whether there are differences in sustainability reports comprehensiveness between the three sustainability dimensions and also between four economic sectors.

\section{Literature review}

There is a widely recognized need for individuals, organizations and societies to find tools for assessing the extent to which current activities are unsustainable (Singh et al, 2009). The sustainability report is one of these tools (Caron \& Turcotte, 2009). This trend has been analyzed under the scope of two theories, the Legitimacy theory and the Stakeholder theory.

The Legitimacy theory states that, in order to maintain its business activities, companies need to behave as to what is expected from society (O’Donovan, 2002). The need to legitimate its actions drive companies into making sustainability reports, as the information disclosed in these documents is important to change society's perception towards the company (Deegan, 2002). Cho and Patten (2007) also support the argument that companies use disclosure as a legitimizing tool.

The stakeholder theory presumes that the values of the companies are an important factor as how they do business, so they need to explicitly alert its stakeholders of those values in order to build a meaningful relationship between them (Freeman et al, 2004). Under that scope, Gray et al (1996) say that companies use the sustainability report to shape stakeholders opinions in a positive way, opening doors for them to keep conducting their business activities. Konar and Cohen (2001) state that major companies tend to voluntarily comply with environmental regulations and externally portray an image of being environmentally concerned, being rewarded in the marketplace for taking these actions.

Hedberg and Malmborg (2003) have found, in their empirical evidence from Swedish companies, that they produce corporate sustainability reports to seek organizational legitimacy. They were particularly interested in reporting their environmental and ethical/social statistics to their financiers. Roca and Searcy (2012) identified a wide variety by theme and sector in the indicators disclosed, which they link to the Legitimacy theory, stating companies' disclosure practices aim to maintain its legitimacy. They also identified that all TBL dimensions were disclosed with relatively equal frequency.

This legitimacy issue was also covered in Stubbs et al study (2012). The drivers for sustainability report differ for the very largest firms. They would see it contributing to reputation, corporate image, competitive advantage and credibility, some want to be listed on the sustainability indexes. Despite studies pointing to legitimacy as a key motivating driver, the firms in their sample do not experience sustained, societal and stakeholder pressure about their social/environmental performance, nor are there stakeholder demands for information about their performance. Perhaps legitimacy is something relevant to only the very largest firms, or is something that is no longer perceived as being obtainable through extended disclosure and sustainability reporting.

Regardless what drives companies to produce sustainability reports and the fact that they are 
not a mandatory report in most countries, these documents are being integrated in the culture of big companies over time (Sridhar, 2012). In fact, the ability to build a performance appraisal system and information management system that provides information about the balance of social, environmental and financial information is essential to maintain the company’s culture of sustainability (Rahardjo et al, 2013).

Despite there are various international efforts to measure sustainability, few of them have an approach taking into account environmental, economic and social aspects (Singh et al, 2009), as it is the case of Global Reporting Initiative (GRI).

Considering that companies from the same economic sectors would be more likely to report the same indicators when using the GRI framework in their reports, Sherman and Diguilio (2010) analyzed the reports from 2008-2009 of eight big companies. They found that companies, even the ones classified as Application Level A, do not disclose the same indicators, leaving a wide range of discrepancy between the indicators reported. Sampaio et al (2012) also tried to identify some kind of isomorphic process in the reports of mining companies between 2005 and 2009, concluding that no such process occurred, even when companies used the GRI guidelines. On a similar approach, Wang and Huang (2010) analyzed the reports of 116 Chinese companies from 2002-2008 and found that the content reported continued to diverge over the years.

Tiong and Ananthamaran (2011) drew attention to the fact that, apart from the low disclosure levels, even Application Level A companies didn't justify the omitted indicators, which is recommended on the GRI guidelines. Analyzing quantity and quality levels of the reports from six Brazilian companies classified as Application Level A+, Leite Filho et al (2009) identified no traces of a good level of disclosure to justify such Application Level whatsoever. Adding to that, Aktas et al (2013) concluded that GRI's indicators are inconsistent within companies stating the same Application Level.

The major similarity between these studies is that all the companies don't seem to follow the guidelines proposed. Application Level A companies would be expected to have a higher level of commitment to the guidelines, which is not apparent in the analyzed reports.

Ching et al (2013) compared the sustainability reports of companies listed on ISE to those of listed in Novo Mercado NM (Brazilian price index of companies with the highest level of corporate governance practices). ISE companies tend to disclose more information in a more adequate way than NM and that all the three TBL aspects are addressed with same quality level.

Morhardt, Baird and Freeman (2002) evaluated the extent to which corporate environmental reports meet the requirement of GRI 2000 guidelines and ISO 14031 performance evaluation standard. They assigned scores to each topic of the guidelines as 0 , not mentioned; 1 , anecdotal or briefly mentioned; 2, more detail, but characterizing only selected facilities or using only self-comparison metrics; 3 , company-wide absolute or relative metrics that could be compared with other companies. They selected the 1999 reports of 40 of the largest global industrial companies. Their most striking result was that the economic and social indicators 
achieved $4,1 \%$, the environmental indicators achieved $3,6 \%$ of the total possible points in GRI score. Also, organizational features and general performance indicators completed the score with $47,9 \%$ and $44,3 \%$ respectively.

On the other hand, Perez and Sanchez (2009) undertake the evolution of sustainability reports of four mining companies, from 2001-2006, identifying that the social aspect was the most reported by those companies, followed by the environmental and economic aspects.

Despite the evidences shown above, Moneva, Archel and Correa (2006) state that GRI guidelines are used in a biased way in the sense that some organizations that label themselves as GRI reporters do not behave in a responsible way with respect to social equity, human rights or gas emissions. For them, the concept of sustainability that underlies the GRI guidelines presents some shortfalls and weaknesses that contribute to perceive it in a simple manner limited to a disclosure of a collection of non-integrated indicators corresponding to the current year.

\section{Methodology and Data Collection}

The companies were chosen due to the nature of the stock exchange indexes: both ISE and FTSE4Good Global Index represent groups of companies that meet globally recognized social and environmental responsibility standards. They are part of BM\&FBovespa (Brazilian Stock Exchange) and LSE (London Stock Exchange) indexes respectively.

We worked with companies that used GRI guidelines on their 2011 sustainability reports. Therefore, only 35 out of 38 companies of ISE were considered. We set that as our comparative number, so the logic approach was to select 35 sustainability reports from companies listed in FTSE4Good Global Index. The following distribution by economic sector of ISE companies is as follows: 8 companies for Financial, 15 for Infrastructure, 10 for Industrial and 2 for Services.

The FTSE4Good Global Index comprises of 729 companies, 511 of those are from the United Kingdom, Japan, France, USA and Australia. These countries were selected due to its representativeness of the price index. We have been through the websites of all these 511 companies to find that only 120 of them used GRI guidelines in 2011. We weighted the representation of each country using the number of reports available from companies located in this index. See table 1 below.

Table 1. Country weights assigned by number of reports in the FTSE4Good sample

\begin{tabular}{cccc}
\hline Position & Country & Weight & $\begin{array}{c}\text { Number of } \\
\text { Reports }\end{array}$ \\
\hline $1^{\circ}$ & USA & $31 \%$ & 37 \\
$2^{\circ}$ & JAPAN & $24 \%$ & 29 \\
$3^{\circ}$ & UK & $21 \%$ & 25 \\
$4^{\circ}$ & FRA & $13 \%$ & 15 \\
$5^{\circ}$ & AUS & $11 \%$ & 14 \\
Total & & & 120 \\
\hline
\end{tabular}


To compare both indexes, ISE and FTSE4Good, using the same number of companies, the weight for each country presented in Table 1 was considered for each economic sector. Example: Japan has a weight of $24 \%$, so the ideal sample would have at least two Japanese companies for the financial sector $(24 \%$ x $8=1,92)$, four for the infrastructure sector $(24 \% \mathrm{x}$ $15=3,6)$, two for the industrial sector $(24 \% \times 10=2,4)$ and zero companies for the services sector $(24 \%$ x $2=0,42)$. Numbers were rounded up to the next unit when the second decimal place was higher or equal to 0,5. Having then calculated the number of companies by economic sector and by country, the companies were selected in a random sort. The final sample is presented in Table 2.

Table 2. FTSE4Good Sample

\begin{tabular}{llllllll}
\hline & JA & USA & UK & FRA & AU & Total \\
\hline Financials & 0 & 3 & 2 & 2 & 1 & 8 & 15 \\
Infrastructure & 4 & 2 & 4 & 2 & 3 & 10 \\
Industrial & 3 & 3 & 3 & 0 & 1 & 2 & \\
Services & 0 & 1 & 1 & 0 & 0 & & 2 \\
\hline
\end{tabular}

The 70 companies were divided into four sectors - Financial, Industrial, Infrastructure and Services (Table 3).

Table 3. Reports Divided by index and Economic sector

\begin{tabular}{cccc}
\hline & ISE & FTSE4Good & Total \\
\hline Financial & 8 & 8 & 16 \\
Infrastructure & 15 & 15 & 30 \\
Industrial & 10 & 10 & 20 \\
Services & 2 & 2 & 4 \\
Total & 35 & 35 & 70 \\
\hline
\end{tabular}

\subsection{Content Analysis}

The qualitative method chosen to conduct our study was content analysis. It consists in collecting and classifying quantitative and qualitative data into pre-defined categories in order to find patterns between the information selected (Guthrie \& Abeysereka, 2006).

We have used GRI pre-defined aspects as per Ching et al (2013) to classify the information found in the reports. The framework proposed by GRI consists in the TBL (economic, social and environmental dimensions) divided in aspects and the indicators under the aspects. For example, the EN1 indicator is inside the category Materials, which is inside the Environmental aspect. The EN1 indicator represents "materials used by weight or volume”.

We classified the indicators present in the reports in three categories: fully reported (when all 
information required by the indicator was disclosed, partially reported (the indicator was partially reported) and not reported (when no information of the indicator was disclosed in the report). Each of these categories has its own score attached (1, 0,5 and 0, respectively).

Example: BicBanco (ISE) reported the EN1 indicator disclosing the amount of paper consumed during the year of 2011, along with the percentage of it that was recycled, receiving the classification fully reported. Northern Trust (FTSE4Good), however, disclosed the indicator informing only the amount of material recycled (without specifying which material is that) and added some vague statements about their commitment with recycling. It was not what the indicator asked, but as it had some relation to the topic and made sense considering the whole of the report, it was classified as partially reported. On the other hand, Bradesco (ISE) and British Land (FTSE4Good) didn't report anything on this indicator, which left them with the classification not reported.

The indicators were used instead of its definition. Similar structures were used by Poser et al (2007) and Morhardt et al (2002). This approach made possible for us to identify the stage of adherence to GRI in the sustainability reports, by analyzing if companies disclosed the indicators and how they disclosed them. Declaring the level of disclosure in these classifications is similar to what GRI proposes companies to do in their reports.

\subsection{Methodology to calculate the scores and use of statistical techniques}

Reporting guidelines are quite incipient scoring systems and Ching et al (2013) took advantage of this to produce a new scoring methodology. We have adopted the same methodology proposed in 4 levels to calculate the scores. The bottom level, with the 79 indicators. We calculated scores (from 0 to 1 ) for each information of the 70 companies individually, based on content analysis. These 79 indicators were aggregated, in an upper level, by aspect (as defined by the GRI guidelines) and the scores, in each aspect, were calculated using arithmetic mean of their respective indicators. Moving up, the aspects were aggregated by dimension (the second level) and their scores were composed using arithmetic mean of their respective aspects. Finally the overall score gathering the scores of the 3 dimensions is the top level. Exception was made for the social dimension, where there is a category level as suggested by GRI guidelines.

By using arithmetic mean, we say that every indicator, to compose the score in each aspect and every aspect in each dimension, has the same weight, despite they (the aspects and dimensions) have greater or lesser amount of indicators.

For instance, the 4 topics of aspect Economic performance together have the same weight as the group of 3 topics of aspect Market presence and as the 2 topics of the aspect Indirect economic impacts. And these 3 aspects in the economic dimension have together the same importance as the 9 aspects of the environmental dimension.

Having the scores calculated, a quantitative approach is employed for statistical analysis. To verify whether the data sets follow a normal distribution, Shapiro-Wilk tests were applied. As we will show later, not all data sets are normally distributed. So, non-parametric statistical tests, as Mann-Whitney and Kruskal-Wallis, were applied. Together with Kruskal-Wallis, 
once statistically significant differences are detected, post-hoc test was used as suggested by Siegel and Castellan (1988) and Daniel (1978).

\section{Findings and Discussion}

\subsection{Ranking the companies}

The analysis of the reports resulted in a ranking, which summarizes the level of adherence to the GRI indicators that companies achieved in all the triple bottom line dimensions. The top 12 companies are listed in Table 4, and the complete list of companies can be seen in the appendix.

Table 4. 12 top General Adherence Level

\begin{tabular}{clllll}
\hline Position & Company & Sector & Country & Index & Score \\
\hline $1^{\circ}$ & Natura & Ind & BR & ISE & 0,924 \\
$2^{\circ}$ & Fibria & Ind & BR & ISE & 0,911 \\
$3^{\circ}$ & Energias BR & Infra & BR & ISE & 0,899 \\
$4^{\circ}$ & Sul America & Fin & BR & ISE & 0,867 \\
$5^{\circ}$ & Cemig & Infra & BR & ISE & 0,848 \\
$6^{\circ}$ & Itaú Unibanco & Fin & BR & ISE & 0,835 \\
$7^{\circ}$ & Coelce & Infra & BR & ISE & 0,835 \\
$8^{\circ}$ & AGL Energy & Infra & AU & FTSE4Good & 0,816 \\
$9^{\circ}$ & CRH & Ind & UK & FTSE4Good & 0,797 \\
$10^{\circ}$ & Banco do Brasil & Fin & BR & ISE & 0,785 \\
$11^{\circ}$ & Anglo American & Infra & UK & FTSE4Good & 0,785 \\
$12^{\circ}$ & Suzano Papel & Ind & BR & ISE & 0,759 \\
\hline \multicolumn{7}{c}{} & & & &
\end{tabular}

ISE companies occupy nine of top 12 first positions in the ranking, while the only three FTSE4Good companies occupy the $8^{\text {th }}$, 9th and $11^{\text {th }}$ positions. Five companies are from the Infrastructure sector, four from the Industrial sector and three from the Financial sector.

Looking to the whole sample, the quality scenario is as follows: $17 \%$ achieved score above 0.75 ; $33 \%$ between 0.51 and 0.75 ; $44 \%$ between 0.26 and 0.5 and $6 \%$ scored below 0.25 .

As shown in Figure 1, FTSE4Good Global Index companies presented 1067 fully reported indicators (39\%), 439 partially reported (16\%) and 1259 not reported (46\%), with an average of 43 indicators per report. ISE companies presented 1425 fully reported indicators (52\%), 389 partially reported (14\%) and 951 not reported (34\%), with an average of 52 indicators per report.

The high percentage of indicators not reported (in both indexes) goes against GRI recommendation. Tiong and Ananthamaran (2011) and Leite et all (2009) also drew attention that companies do not justify the omitted indicators. 


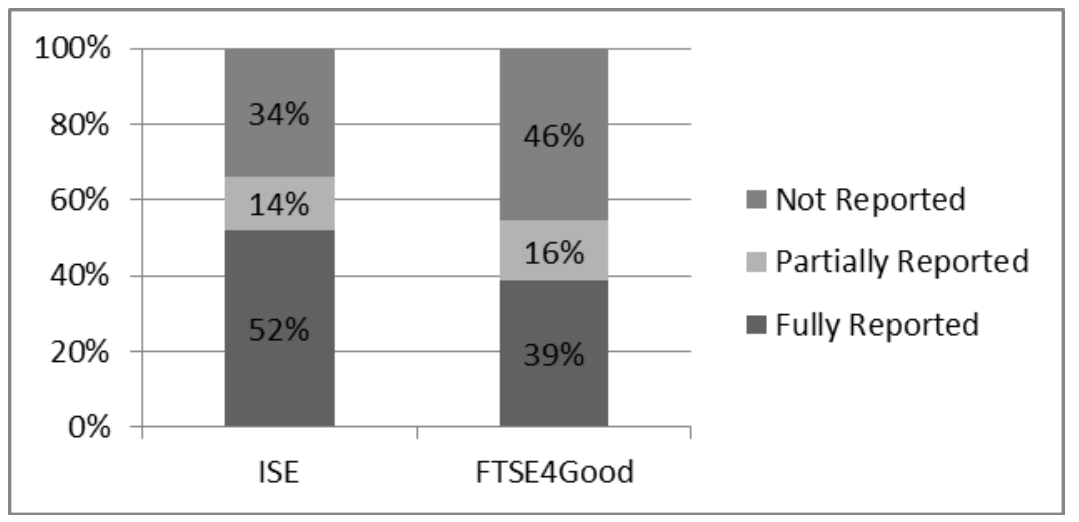

Figure 1. Reporting comparison between ISE and FTSE4Good

The most disclosed indicators of all the reports (appearing in more than 53 reports, which represent $75 \%$ of the total sample) are presented in Table 5. These sixteen indicators represent $17 \%$ of the total amount of reported indicators. Eight of then are form social aspect, seven from environmental and one from economic aspect. This finding is in line with Perez and Sanchez (2009) where the social aspect was the most reported, followed by environmental and economic. Moreover, LA1, EN16 and EC1 were also noted by Roca and Searcy (2012) as three of the most reported indicators in their study. 
Table 5. Most frequent indicators disclosed and their respective descriptions

\begin{tabular}{|c|c|c|}
\hline $\begin{array}{l}\text { Indicator } \\
\text { Code }\end{array}$ & Frequency & Description \\
\hline LA1 & 66 & Total workforce by employment type, employment contract, and region. \\
\hline N16 & 64 & Total direct and indirect greenhouse gas emissions by weight. \\
\hline LA13 & 64 & $\begin{array}{l}\text { Composition of governance bodies and breakdown of employees per category } \\
\text { according to gender, age group, minority group membership, and other } \\
\text { indicators of diversity. }\end{array}$ \\
\hline EN3 & 58 & Direct energy consumption by primary energy source. \\
\hline EN18 & 58 & Initiatives to reduce greenhouse gas emissions and reductions achieved. \\
\hline LA8 & 58 & $\begin{array}{l}\text { Education, training, counseling, prevention, and risk-control programs in } \\
\text { place to assist workforce members, their families, or community members } \\
\text { regarding serious diseases. }\end{array}$ \\
\hline EN26 & 57 & $\begin{array}{l}\text { Initiatives to mitigate environmental impacts of products and services, and } \\
\text { extent of impact mitigation. }\end{array}$ \\
\hline SO1 & 57 & $\begin{array}{l}\text { Nature, scope, and effectiveness of any programs and practices that assess and } \\
\text { manage the impacts of operations on communities, including entering, } \\
\text { operating, and exiting. }\end{array}$ \\
\hline EC1 & 56 & $\begin{array}{l}\text { Direct economic value generated and distributed, including revenues, } \\
\text { operating costs, employee compensation, donations and other community } \\
\text { investments, retained earnings, and payments to capital providers and } \\
\text { governments. }\end{array}$ \\
\hline EN22 & 55 & Total weight of waste by type and disposal method. \\
\hline LA4 & 55 & Percentage of employees covered by collective bargaining agreements. \\
\hline LA7 & 55 & $\begin{array}{l}\text { Rates of injury, occupational diseases, lost days, and absenteeism, and } \\
\text { number of work related fatalities by region. }\end{array}$ \\
\hline LA12 & 55 & $\begin{array}{l}\text { Percentage of employees receiving regular performance and career } \\
\text { development reviews. }\end{array}$ \\
\hline EN4 & 54 & Indirect energy consumption by primary source. \\
\hline SO5 & 54 & $\begin{array}{l}\text { Public policy positions and participation in public policy development and } \\
\text { lobbying. }\end{array}$ \\
\hline EN8 & 53 & Total water withdrawal by source. \\
\hline
\end{tabular}




\subsection{Adherence level per economic sector and index}

Table 6 shows a descriptive statistics of the total sample (70 companies), of each index group (ISE and FTSE4Good) and of each economic sector. The score of the total sample was of 0.5159. ISE companies achieved a higher score than FTSE4Good companies, 0.5867 and 0.4451 respectively. These results are in line with those in table 2, in which nine of top 12 companies with the best scores are from ISE. By economic sector, infrastructure has the highest score (0.5626) followed by industrial (0.5117), financial (0.4942) and services (0.2724).

Table 6. Descriptive summary for the score of the company subsets

\begin{tabular}{lcccccc}
\hline Subset & $\mathrm{N}$ & Mean & Std. Deviation & Std. Error & Minimum & Maximum \\
\hline AllCompanies & 70 & .5159 & .2181 & - & .1046 & .9484 \\
Fin & 16 & .4942 & .2066 & .0516 & .2344 & .8684 \\
Infra & 30 & .5626 & .2104 & .0384 & .1046 & .8819 \\
Ind & 20 & .5117 & .2313 & .0517 & .2237 & .9484 \\
Serv & 4 & .2724 & .1034 & .0517 & .1943 & .4245 \\
ISE & 35 & .5867 & .2199 & .0371 & .2237 & .9484 \\
FTSE4Good & 35 & .4451 & .1946 & .0329 & .1046 & .8314 \\
\hline
\end{tabular}

The next step is to decide the use of parametric or nonparametric statistical approach in our sample. Shapiro-Wilk nonparametric normality test was applied and table 7 shows the goodness of fit results when all companies are taken together and when they are separated in economic sectors and in index groups.

Using a 0.05 significance level, all the results for total sample, by index group and by economic sector, do not present as a normal probability distribution. This can be seen in the p-value column. When p-value is lower than the significance level assumed for the test the null hypothesis is rejected. So, assuming a conservative approach, the analysis will be performed using nonparametric statistical tests, such as Kuskal-Wallis and Mann-Whitney. 
Table 7. Normality test

\begin{tabular}{lccc}
\hline \multirow{2}{*}{$\begin{array}{l}\text { Companies } \\
\text { subsets }\end{array}$} & \multicolumn{3}{c}{ Shapiro-Wilk } \\
\cline { 2 - 4 } & Statistic & DF & p. value \\
\hline Financial & .869 & 16 & $\mathbf{. 0 2 6}$ \\
Infrastructure & .956 & 30 & .241 \\
Industrial & .922 & 20 & .106 \\
Services & .804 & 4 & .110 \\
ISE & .945 & 35 & .082 \\
FTSE4Good & .937 & 35 & $\mathbf{. 0 4 4}$ \\
\hline
\end{tabular}

Table 8 shows the multiple comparison Kruskal-Wallis nonparametric test across the four distinct economic sectors. Using 0.05 significance level, this test points that there is no significant differences in the sectors, as can be seen in the Asymp. p-value. In other words, results show that the level of adherence to the GRI indicators is the same across all sectors.

Table 8. Kruskal-Wallis multiple comparison among the four economic sectors

\begin{tabular}{lcclc}
\hline Sector & $\mathrm{N}$ & MeanRank & \multicolumn{2}{c}{ Test Statistics ${ }^{\text {a.b }}$} \\
\hline Financial & 16 & 33.69 & Chi-Square & 7.683 \\
Infra & 30 & 40.37 & Df & 3 \\
Industrial & 20 & 34.55 & Asymp. p-value & .053 \\
Services & 4 & 11.00 & & \\
Total & 70 & & & \\
\hline
\end{tabular}

a. Kruskal Wallis Test

b. Grouping Variable: Sector

\subsection{Analysis of quality of information disclosed by 3 sustainability dimensions}

Table 9 shows a descriptive statistics of the total sample (70 companies) in each dimension. The scores of the three dimensions are relatively even. Companies that reported in the economic, environmental and social dimensions scored 0.5214, 0.4957 and 0.5305 respectively.

Table 9. Descriptive summary of the sustainability dimensions

\begin{tabular}{ccccccc}
\hline Dimension & $\mathrm{N}$ & Mean & Std. Deviation & Std. Error & Minimum & Maximum \\
\hline Economical & 70 & .5214 & .2602 & .0311 & .0000 & 1.0000 \\
Envrironmental & 70 & .4957 & .2487 & .0297 & .0555 & .9944 \\
Social & 70 & .5305 & .2395 & .0286 & .1101 & .9458 \\
\hline
\end{tabular}




\section{Macrothink}

Journal of Management Research

ISSN 1941-899X

2014, Vol. 6, No. 3

When separated by index, the Kruskal-wallis test revealed that there is no difference in the adherence level among the dimensions (Table 10). Therefore, hypothesis 4 is accepted: the level of adherence is equivalent for every sustainability dimension within companies of the same index.

Table 10. Kruskal-wallis test for each dimension per index

\begin{tabular}{cccclc}
\hline & Dimension & $\mathrm{N}$ & Mean Rank & \multicolumn{2}{c}{ Test Statistics } \\
\hline \multirow{2}{*}{ ISE } & Economical & 35 & 55.03 & Chi-Square & 1.573 \\
& Environmental & 35 & 47.77 & Df & 2 \\
& Social & 35 & 56.20 & Asymp. p-value & .455 \\
& Total & 105 & & & \\
& Economical & 35 & 51.03 & Chi-Square & .562 \\
& Environmental & 35 & 56.11 & Df & 2 \\
& Social & 35 & 51.86 & Asymp. p-value & .755 \\
& Total & 105 & & & \\
\hline
\end{tabular}

Roca and Searcy (2012) and Ching et al (2014) came to the same results thal all TBL aspects are disclosed with same quality level.

Table 11 shows the goodness of fit results using 0.05 significance level. All the dimensions results cannot be considered as normally distributed variables. This can be seen in the p-value column. Based on this finding, the non-parametric Kruskal-Wallis comparison test was applied (Table 12).

Table 11. Normality tests for all dimensions and indexes

\begin{tabular}{cccc}
\hline Dimension & \multicolumn{3}{c}{ Shapiro-Wilk } \\
\cline { 2 - 4 } Economical & Statistic & Df & p-value \\
\cline { 2 - 4 } ISE & .969 & 35 & .416 \\
FTSE & .972 & 35 & .492 \\
Environmental & & & \\
ISE & .923 & 35 & $\mathbf{. 0 1 7}$ \\
FTSE & .963 & 35 & .276 \\
Social & & & \\
ISE & .959 & 35 & .215 \\
FTSE & .889 & 35 & $\mathbf{. 0 0 2}$ \\
\hline
\end{tabular}


Table 12. Kruskal-Wallis test for each index and sustainability aspect

\begin{tabular}{llcclc}
\hline Aspect & Sector & $\mathrm{N}$ & Mean Rank & \multicolumn{2}{c}{ Test Statistics } \\
\hline Economical & Financcial & 16 & 34.56 & Chi-Square & 4.153 \\
& Infrastructure & 30 & 38.73 & Df & 3 \\
& Industrial & 20 & 35.13 & Asymp. p-value & .245 \\
& Services & 4 & 16.88 & & \\
Environmental & Financcial & 16 & 32.28 & Chi-Square & 9.489 \\
& Infrastructure & 30 & 40.32 & Df & 3 \\
& Industrial & 20 & 36.38 & Asymp. p-value & .023 \\
Social & Services & 4 & 7.88 & & 3.177 \\
& Financcial & 16 & 35.28 & Chi-Square & 3 \\
& Infrastructure & 30 & 38.48 & Df & .365 \\
& Industrial & 20 & 34.40 & Asymp. p-value & \\
& Services & 4 & 19.50 & &
\end{tabular}

This test points to a difference observed in the environmental dimension in the GRI adherence between the companies, as can be seen in the Asymp. p-value (see table 12). Kruskal-Wallis test, however, does not indicate in which sector this difference can be found. In order to find this, the post-hoc tests suggested by Siegel and Castellan (1988) and Daniel (1978) were applied. The results revealed that the Infrastructure sector is more adherent than the Services sector for the Environmental dimension. Sampaio et al (2012) and Davys and Searcy (2010) indicated in their studies that infrastructure companies are the ones with the higher number of reports and have a tendency to be more adherent to worldwide frameworks (such as GRI).

We found significant differences in the quality of the sustainability reports in the two index groups. ISE companies present reports more adherent in the economic and social dimensions than FTSE4Good (see table 13) Therefore, H1 and H3 hypotheses are rejected. The data provide no conclusion regarding the environmental dimension (H2). 
Table 13. Mann-Whitney tests for all dimensions and indexes

\begin{tabular}{llccclc}
\hline & Group & $\mathrm{N}$ & Mean Rank & Sum of Ranks & \multicolumn{2}{c}{ Mann-Whitney Test } \\
\hline Econômico & ISE & 35 & 42.29 & 1480.00 & Mann-Whitney U & 375.000 \\
& FTSE & 35 & 28.71 & 1005.00 & Wilcoxon W & 1005.000 \\
& Total & 70 & & & Z & -2.791 \\
& & & & & Asymp. p-value (2-tailed) & $\mathbf{, 0 0 5}$ \\
Ambiental & ISE & 35 & 38.20 & 1337.00 & Mann-Whitney U & 518.000 \\
& FTSE & 35 & 32.80 & 1148.00 & Wilcoxon W & 1148.000 \\
& Total & 70 & & & Z & -1.110 \\
\multirow{5}{*}{ Social } & & & & & Asymp. p-value (2-tailed) &, 267 \\
& ISE & 35 & 42.64 & 1492.50 & Mann-Whitney U & 362.500 \\
& FTSE & 35 & 28.36 & 992.50 & Wilcoxon W & 992.500 \\
& Total & 70 & & & Z & -2.937 \\
& & & & & Asymp. p-value (2-tailed) & $\mathbf{, 0 0 3}$ \\
\hline
\end{tabular}

\section{Conclusion}

This paper analyzed companies' sustainability reports from two index: FTSE4Good and ISE. Despite GRI framework is globally accepted and used by most companies around the world, only 23\% of the FTSE4Good sample adopted GRI guidelines. This shows there is not yet a well established world standard framework to report sustainability. Also, results showed that, in general, less than $50 \%$ of the GRI indicators are fully reported and $40 \%$ of them are not reported at all. Companies need to disclose their information in a more integrated way, addressing sustainability issues under the scope of business strategy.

We examined the sustainability reports of seventy companies and, based on content analysis, developed a scoring system (from 0 to 1 ) reflecting the adherence to GRI indicators in those reports in order to test two types of hypothesis:

The companies listed in a benchmark sample (FTSE4Good) are more adherent to the GRI indicators in all sustainability dimensions (economic, environmental and social) than those companies listed in a newer index (ISE);

The level of adherence to GRI indicators, within the companies listed in the same index is equivalent for every sustainability dimension.

According to first hypothesis type, FTSE4Good companies were expected to have more adherences to GRI than ISE because of the reasons displayed: it is a global index, while ISE is a local index; has more expressive values in market capitalization and has also bigger number of companies. This did not prove quite right, however there is still room for improvement for both indexes. The results revealed no distinction in the environmental dimension. Two possible explanations for this finding could be offered: a) because the ISE index is more recent, it was built based on experiences of other indexes that preceded and may have inherited their good practices; b) due to the fact that companies from both indexes compete globally to attract investments and ISE companies are in emerging market, the latter 
are giving a credibility aspect to their reports to attract investors. ISE companies presented a higher level of adherence to the GRI indicators in the economic and social dimensions. Good sustainability reports showing deeper sustainability concerns and business practices related are aligned to the Stakeholder and Legitimacy theories.

Within the same index, companies are reporting the indicators in all the three dimensions with equivalent adherence, which accepts the second type of hypothesis of this study. A good sustainability report is directly related to the good content in all the tree dimensions. Also, the companies, regardless of economic sector, pay similar attention in all dimensions. This behavior confirms Ching et al study (2013) and it is present again in FTSE4Good sample. Furthermore, considering the whole sample and the sectors in which the companies were divided, the Infrastructure sector presents more adherences to the environmental dimension when compared to the Service sector.

In any case, as stated by Okoye et al (2013), managing the social and environmental cravings of the stakeholders is essential to maintain a long term relationship between these stakeholders and the company. We can say that, by disclosing sustainability reports, companies are acting according to the Stakeholder and Legitimacy theories, regardless of their level of adherence to GRI and/or compliance with reporting standards.

As suggestion for a future study, this research could be repeated comparing with other price indexes, such as Dow Jones, Tokyo Stock Exchange or Frankfurt Stock Exchange.

\section{References}

Aktas, R., Kayalidere, K., \& Kargin, M. (2013). Corporate Sustainability Reporting and Analysis of Sustainability Reports in Turkey. International Journal of Economics and Finance, 5(3), 113-125. http://dx.doi.org/10.5539/ijef.v5n3p113

Caron, M. A., \& Turcotte, M. F. B. (2009). Path Dependence and Path Creation: framing the extra-financial information market for a sustainable trajectory. Accounting, Auditing \& Accountability Journal, 22(2), 272-297. http://dx.doi.org/10.1108/09513570910933979

CERES Coalition for Environmentally Responsible Economy. (2010). The 21st century corporation: The Ceres Roadmap for Sustainability.

Ching, H. Y., Gerab, F., \& Toste, T. (2013). Analysis of Sustainability Reports and Quality of Information Disclosed of Top Brazilian Companies. International Business Research, 6(10), 62-77. http://dx.doi.org/10.5539/ibr.v6n10p62

Cho, C. H., \& Patten, D. M. (2007) The role of environmental disclosures as tools of legitimacy: A research note. Accounting. Organization and Society, 32(7-8), 639-647. http://dx.doi.org/10.1016/j.aos.2006.09.009

Daniel, W. W. (1978). Applied Nonparametric Statistics. Boston, MS: Houghton Mifflin Company.

Davys, C., \& Searcy, C. (2010). A review of Canadian Corporate Sustainable Development Reports. Journal of Global Responsibility, 1(2), 316-329. 
http://dx.doi.org/10.1108/20412561011079425

Deegan, C. (2002). The legitimizing effect of social and environmental disclosures - a theoretical foundation. Accounting, Auditing \& Accountability Journal, 15(3), 282-311. http://dx.doi.org/10.1108/09513570210435852

Economist Intelligence Unit EIU. (2008). Doing good: Business and the sustainability challenge.

Federation des Experts Comptables Europeens FEE. (1998). Towards a Generally Accepted Framework for Environmental Reporting. FEE, Bruxelles.

Freeman, R. E., Wicks, A. C., \& Parmar, B. (2004). Stakeholder Theory and The Corporate Objective Revisited. Organization Science, 15(3), 364-369. http://dx.doi.org/10.1287/orsc.1040.0066

Gray, R., Kouhy, R., \& Lavers, S. (1996). Corporate Social and Environmental Reporting: A Review of the Literature and a Longitudinal Study of UK Disclosure. Accounting, Auditing \& Accountability Journal, 8(2), 47-77. http://dx.doi.org/10.1108/09513579510146996

Guthrie, J., \& Abeysekera, I. (2006). Content analysis of social, environmental reporting: What is new? Journal of Human Resource Costing \& Accounting, 10(2), 114-126.

Hedberg, C. J., von Malmborg, F. (2003). The global reporting initiative and corporate sustainability reporting in Swedish companies. Corporate Social Responsibility and Environmental Management, 10, 153-164. http://dx.doi.org/10.1002/csr.38

International Integrated Reporting Council IIRC. (2013). The International IR Framework. Available:

http://www.theiirc.org/wp-content/uploads/2013/12/13-12-08-THE-INTERNATIONAL-IR-F RAMEWORK-2-1.pdf. (February 10, 2014)

Isarksson, R., \& Steimle, U. (2009). What does GRI-reporting tell us about corporate sustainability? The TQM Journal, 21(2), 168-181. http://dx.doi.org/10.1108/17542730910938155

KPMG. Corporate Sustainability:. A Progress Report. (2011). Available: http://www.kpmg.com/Global/en/IssuesAndInsights/ArticlesPublications/Documents/corpora te-sustainability-v2.pdf. (September 3, 2012)

Konar, S., \& Cohen, M. A. (2001). Does the market value environmental performance? The Review of Economics and Statistics, 83(2), 281-289. http://dx.doi.org/10.1162/00346530151143815

Leite Filho, G. A., Prates, L. A.,\& Guimarães, T. N. (2009). Analysis of levels disclosure of sustainability reports of Brazilian companies A+ The Global Reporting Initiative GRI - 2007. RCO - Revista de Contabilidade e Organizações - FEA-RP/USP, 3(7), 43-59.

Lo, S., \& Sheu, H. (2007). Is Corporate Sustainability a Value-Increasing Strategy for Business? Corporate Governance: An International Review, 15(2), 345-358. 
http://dx.doi.org/10.1111/j.1467-8683.2007.00565.x

López, M. V., Garcia, A., \& Rodriguez, L. (2007). Sustainable Development and Corporate Performance: A Study Based on the Dow Jones Sustainability Index. Journal of Business Ethics, 75, 285-300. http://dx.doi.org/10.1007/s10551-006-9253-8

Moneva, J. M., Archel, P., \& Correa, C. (2006). GRI and the camouflaging of corporate unsustainability. Accounting Forum, 30(2), 121-137. http://dx.doi.org/10.1016/j.accfor.2006.02.001

Morhardt, J., E., Baird, S., \& Freeman, K. (2002). Scoring Corporate Environmental and Sustainability Reports Using GRI 2000, ISO 14031 and other criteria. Corporate Social Environmental Management, 9, 215-233. http://dx.doi.org/10.1002/csr.26

O’Donovan, G. (2002). Environmental disclosures in the annual report: Extending the applicability and predictive power of legitimacy theory. Accounting, Auditing \& Accountability Journal, 15(3), 344 - 371. http://dx.doi.org/10.1108/09513570210435870

Okoye, P. V. C., Egbunike, F. C., \& Meduoye, O. M. (2013) Sustainability Reporting: a paradigm for stakeholder conflict management. International Business Research, 6(5), 157-167. http://dx.doi.org/10.5539/ibr.v6n5p157

Perez, F., \& Sanchez, L. E. (2009). Assessing the Evolution of Sustainability Reporting in the Mining Sector. Environmental Management, 43, 949-961. http://dx.doi.org/10.1007/s00267-008-9269-1

Poser, C., Guenther, E., \& Hoppe, H. (2007). Environmental Corporate Social Responsibility of Firms in the Mining and Oil and Gas Industries. Greener Management International, 53, 6-25. http://dx.doi.org/10.9774/GLEAF.3062.2006.sp.00003

Public Environmental Reporting Initiative PERI. (1993). PERI Guidelines. Available: http://www.ibm.com/ibm/environment/initiatives/peri.phtr. (February 11, 2002)

Rahardjo, H., Idrus, M. S., Djumilah, H., \& Siti, A. (2013). Factors that determines the success of Corporate Sustainability management. Journal of Management Research, 5(2). http://dx.doi.org/10.5296/jmr.v5i2.2993

Roca, L. C., \& Searcy, C. (2012). An Analysis of indicators disclosed in corporate sustainability reports. Journal of Cleaner Production, 20, 103-118. http://dx.doi.org/10.1016/j.jclepro.2011.08.002

Sampaio, M. S., Gomes, S. M. S, Bruni, A. L., \& Dias Filho, J. M. (2012). Evidenciação de informações ambientais e isomorfismo: um estudo com mineradoras brasileiras. Revista Universo Contábil, 8(1), 105-122. http://dx.doi.org/10.4270/RUC.2012107

Sherman, W. R.; \& Diguilio, L. (2010). The Second Round Of G3 Reports: Is Triple Bottom Line Reporting Becoming More Comparable? Journal of Business \& Economics Research; 8(9), 59-78

Siegel, S., \& Castellan, N. J. (1988). Nonparametric Statistics for the Behavioral Sciences. 
(2nd edition). New York, NY: McGraw-Hill.

Singh, R. K., Murty, H. R., Gupta, S. K., \& Dikshit, A. K. (2009). An overview of sustainability assessment methodologies. Ecological Indicators, 9, 189-212. http://dx.doi.org/10.1016/j.ecolind.2011.01.007

Sridhar, K. The Relationship between the Adoption of Triple Bottom Line and Enhanced Corporate Reputation and Legitimacy. (2012). Corporate Reputation Review, 15, 69-87. http://dx.doi.org/10.1057/crr.2012.4

Stubbs, W., Higgins, C., \& Milne, M. (2012). Why do companies not produce sustainability reports? Business Strategy and the Environment, 456-470. Published on line in Wiley Online Library. http://dx.doi.org/10.1002/bse.1756

Tiong, P. N. C., \& Ananthamaran, R. N. (2011). An Examination of the Sustainability Disclosures of ANZ, ANB and Westpac. JASSA The Finsia Journal of Applied Finance, 3.

UNEP - SustainAbility. (2000). The Global Reporters: the 2000 Benchmark Survey. SustainAbility, London.

Wang, A., Huang, T. Sustainability Reports in China: Content Analysis. (2010). International Conference of Future Information Technology and Management Engineering (FITME). Changzou: China. 154-158. http://dx.doi.org/10.1109/FITME.2010.5654711

\section{Appendix}

Appendix 1. Complete list of analyzed companies

\begin{tabular}{cccccccc}
\hline Company Name & Sector & Country & Index & Company Name & Sector & Country & Index \\
\hline AES Tietê & Infra & BR & ISE & AGL Energy & Infra & AU & FTSE4Good \\
Anhanguera & Serv & BR & ISE & Air Products And Chemcom & Infra & USA & FTSE4Good \\
Banco do Brasil & Fin & BR & ISE & Amcor & Ind & AU & FTSE4Good \\
BicBanco & Fin & BR & ISE & Anglo American & Infra & UK & FTSE4Good \\
Bradesco & Fin & BR & ISE & Asahi Kasei Corporation & Infra & JA & FTSE4Good \\
Braskem & Ind & BR & ISE & BHP Billiton & Infra & UK & FTSE4Good \\
BRF Foods & Ind & BR & ISE & British Land & Fin & UK & FTSE4Good \\
Cemig & Infra & BR & ISE & CRH & Ind & UK & FTSE4Good \\
Cesp & Infra & BR & ISE & Foncière des Regions & Fin & FRA & FTSE4Good \\
Coelce & Infra & BR & ISE & HCP & Fin & USA & FTSE4Good \\
Copasa & Infra & BR & ISE & InterContinental Hotels Group & Serv & UK & FTSE4Good \\
Copel & Infra & BR & ISE & International Paper & Infra & USA & FTSE4Good \\
CPFL Energia & Infra & BR & ISE & Johnson Matthey & Infra & UK & FTSE4Good \\
Duratex & Ind & BR & ISE & Kimberly-Clark & Ind & USA & FTSE4Good \\
Eletrobrás & Infra & BR & ISE & Lloyds Banking & Fin & UK & FTSE4Good \\
Eletropaulo & Infra & BR & ISE & Lonmin & Infra & UK & FTSE4Good \\
Embraer & Ind & BR & ISE & Man Group & Ind & UK & FTSE4Good \\
Energias BR & Infra & BR & ISE & Marriott International & Serv & USA & FTSE4Good \\
Even & Serv & BR & ISE & Mitsubishi Chemical Holdings & Infra & JA & FTSE4Good \\
\hline
\end{tabular}




\begin{tabular}{|c|c|c|c|c|c|c|c|}
\hline 110 & 45 & & & \multicolumn{4}{|c|}{$\begin{array}{r}\text { Journal of Management Research } \\
\text { ISSN 1941-899X } \\
\text { 2014, Vol. 6, No. } 3\end{array}$} \\
\hline Fibria & Ind & $\mathrm{BR}$ & ISE & Mohawk Industies & Ind & USA & FTSE4Good \\
\hline Industrias Romi & Ind & $\mathrm{BR}$ & ISE & Natixis & Fin & FRA & FTSE4Good \\
\hline Itaú S.A & Fin & $\mathrm{BR}$ & ISE & Nikon Corp & Ind & JA & FTSE4Good \\
\hline Itaú Unibanco & Fin & $\mathrm{BR}$ & ISE & Northern Trust & Fin & USA & FTSE4Good \\
\hline Light S/A & Infra & $\mathrm{BR}$ & ISE & NTT Docomo & Infra & JA & FTSE4Good \\
\hline Natura & Ind & $\mathrm{BR}$ & ISE & Orica & Infra & $\mathrm{AU}$ & FTSE4Good \\
\hline Oi (Telemar) & Infra & BR & ISE & Panasonic Corp & Ind & JA & FTSE4Good \\
\hline Redecard & Fin & $\mathrm{BR}$ & ISE & Procter \& Gamble & Ind & USA & FTSE4Good \\
\hline Sabesp & Infra & $\mathrm{BR}$ & ISE & Reckitt Benckiser Group & Ind & UK & FTSE4Good \\
\hline Santander Brasil & Fin & $\mathrm{BR}$ & ISE & Stockland & Fin & $\mathrm{AU}$ & FTSE4Good \\
\hline Sul America & Fin & $\mathrm{BR}$ & ISE & Suez Environment & Infra & FRA & FTSE4Good \\
\hline Suzano Papel & Ind & $\mathrm{BR}$ & ISE & Sumitomo Chemical & Infra & JA & FTSE4Good \\
\hline TIM & Infra & $\mathrm{BR}$ & ISE & Telstra Corp & Infra & $\mathrm{AU}$ & FTSE4Good \\
\hline Tractabel & Infra & $\mathrm{BR}$ & ISE & Total & Infra & FRA & FTSE4Good \\
\hline Ultrapar & Ind & $\mathrm{BR}$ & ISE & Toyota Motor & Ind & JA & FTSE4Good \\
\hline Vale & Ind & $\mathrm{BR}$ & ISE & Wells Fargo & Fin & USA & FTSE4Good \\
\hline
\end{tabular}

